\title{
Fine-Needle Aspiration Cytology of Metastatic Eccrine Porocarcinoma
}

\author{
Limin Yu, M.D., Stephen Olsen, M.D., Lori Lowe, M.D., \\ Claire Michael, M.D., and Xin Jing, M.D.*
}

Eccrine porocarcinoma (EP), although rare, is widely recognized as the most common malignant sweat gland tumor. EP typically grows slowly and usually is cured by surgical excision with clear margins. An elevated mortality rate, however, is observed when regional lymph nodes are involved. We herein describe cytohistologic findings in a case of metastatic EP. An 86-year-old man with a history of EP of the left lateral ankle and squamous cell carcinoma in situ (Bowen's disease) of the penis presented with enlarged left inguinal lymph nodes. A superficial fine-needle aspiration (FNA) was performed and demonstrated a hypercellular sample with discohesive clusters and or individual tumor cells. The tumor cells were round or oval with most of the cells showing dense, refractile cytoplasm. Intracytoplasmic vacuoles were readily appreciated in some of the cells. Nuclear enlargement, high N/C ratio, nuclear hyperchromasia, bi- and multinucleation, and prominent nucleoli were seen. A diagnosis of metastatic eccrine porocarcinoma was rendered. Enlarged retroperitoneal lymph nodes were detected and CT-guided left retroperitoneal core biopsy was performed 1 week later. The biopsy revealed features consistent with metastatic eccrine porocarcinoma. Diagn. Cytopathol. 2009;37:755758. 2009 Wiley-Liss, Inc.

Key Words: fine-needle aspiration; cytology of porocarcinoma; metastatic porocarcinoma

Eccrine porocarcinoma (EP) is a rare malignant adnexal tumor of the skin derived from the eccrine sweat gland. Pinkus and Mehregan first described the entity in $1963^{1}$ and Mishima and Morioka introduced the term of EP later in $1969 .^{2}$ The tumor reported by the latter authors was described as an intraepidermal proliferation of tumor cells and intraepidermal ducts among the tumor cells, the latter

Department of Pathology, University of Michigan Health System, 1500 E. Medical Center Drive, Ann Arbor, Michigan 48108

*Correspondence to: Xin Jing, M.D., Department of Pathology, University of Michigan Health System, 1500 E. Medical Center Drive, Ann Arbor, MI 48108. E-mail: xinjing@med.umich.edu

Received 5 December 2008; Accepted 7 March 2009

DOI 10.1002/dc.21099

Published online 29 April 2009 in Wiley InterScience (www.interscience. wiley.com). resembled eccrine sweat ducts in the epidermis and clefts. The authors further identified the intraepidermal portion of the errcrine sweet duct (the acrosyringium) as the point of origin of the tumor and the term of porocarcinoma (poro $=$ duct) was thus coined. EP may result from malignant transformation of a benign eccrine poroma or occur de novo. ${ }^{3-5}$ The largest series of cases studied to date demonstrated that EP most commonly involves lower extremities, trunk, and head. ${ }^{6}$ There is a predilection for elderly patients in the fifth to eighth decades of life. ${ }^{7-10}$ Inconsistent observations have been reported with regard to gender preference. ${ }^{11-14}$ The natural course of EP varies. EP characteristically grows slowly and is usually cured by wide surgical excision with clear margins. ${ }^{15}$ However, this neoplasm may behave in a more aggressive fashion and $\sim 20 \%$ of patients experience local recurrence and/or regional lymph node metastasis. ${ }^{1,4,11}$ When regional lymph nodes are involved, an elevated mortality rate of $>65 \%$ is observed. ${ }^{11}$ We herein report the cytohistologic findings in a case of EP that metastasized to regional lymph nodes.

\section{Case Reports}

An 86-year-old man with a history of EP of the left lateral ankle and squamous cell carcinoma in situ (Bowen's disease) of the penis, presented with a $0.5-\mathrm{cm}$ palpable left inguinal lymph node. A superficial fine-needle aspiration (FNA) of a left inguinal lymph node was performed using a 25-gauge needle. A total of five passes were performed. For each pass, two direct smears were prepared and the needle was then rinsed in the CytoLyt solution from which a cell block was prepared and a 4- $\mu$ m section was stained with hematoxylin and eosin. Half of the smears were air-dried and stained with Diff-Quick. The remaining smears were rapidly fixed by the Sprayfix ${ }^{\mathrm{TM}}$ and later stained with Papanicolaou technique. The smears were hypercellular and consisted of discohesive sheets and clusters of round and oval neoplastic cells, as well as 

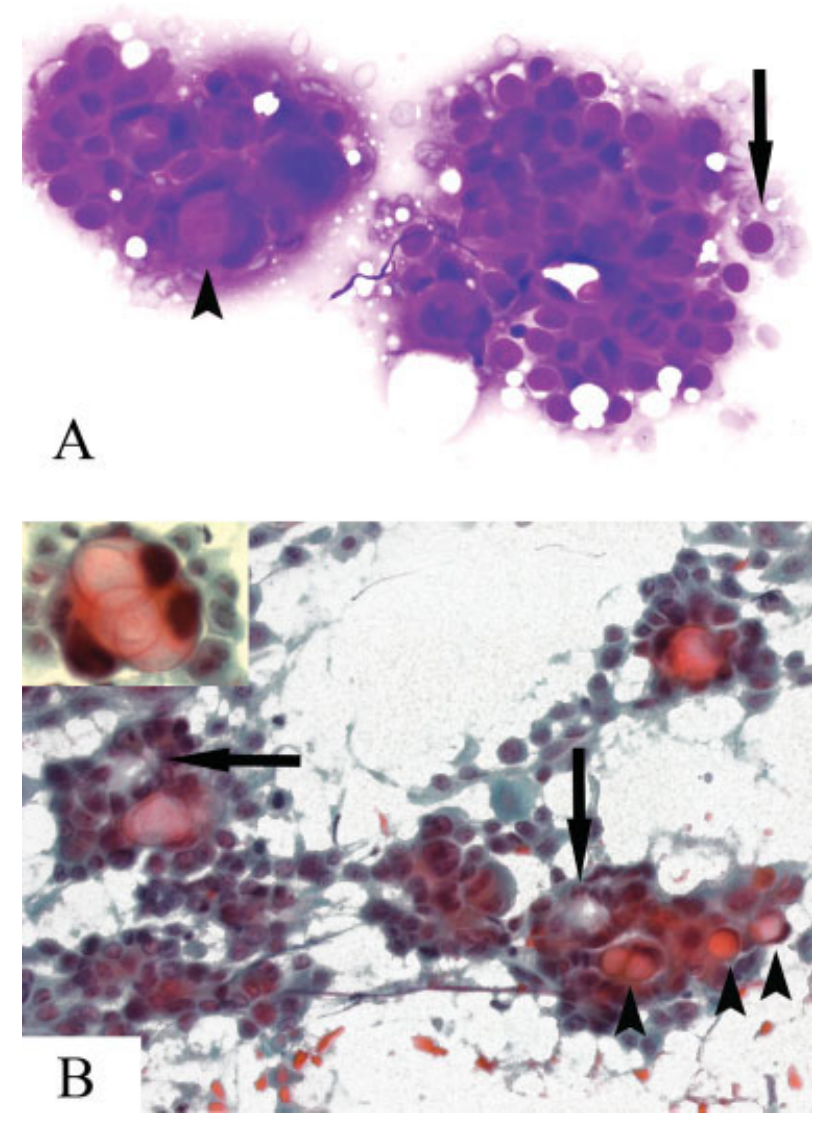

Fig. 1. Diff-Quik stain (A) and Pap stain (B) show clusters of neoplastic cells with high N/C ratio, nuclear pleomorphism, hyperchromasia, and occasionally prominent nucleoli. A: Cells with squamoid features (arrow), and intracytoplasmic vacuoles (arrowhead) in Diff-Quik (×400). B: Intracytoplasmic vacuoles (arrowhead) and acinar configuration (arrow) in $\mathrm{Pa}$ panicolaou stain $(\times 400)$. The insert also shows intracytoplasmic vacuoles (Papanicolaou stain, $\times 600$ ). [Color figure can be viewed in the online issue, which is available at www.interscience.wiley.com.]

single scattered cells. Some cells showed squamoid features that were manifested by ill- to well-defined intercellular boarder, moderate to dense refractile cytoplasm which appeared deep blue on Diff-Quick stain and cyanophilic on Papanicolaou stain. Other cells attempted to form acini and exhibited intracytoplasmic vacuoles. High $\mathrm{N} / \mathrm{C}$ ratio, nuclear enlargement, pleomorphism in size and shape of nuclei, nuclear hyperchromasia, and occasionally prominent nucleoli were appreciated (Fig. 1). Bi- and multinucleation were rarely seen. The cell block contained some tumor cells with intracytoplasmic vacuoles which were highlighted with polyclonal carcinoembryonic antigen (CEA) antibody. Based upon these findings, a diagnosis of metastatic eccrine porocarcinoma was rendered.

Enlarged retroperitoneal lymph nodes were detected and CT-guided left retroperitoneal core biopsy was per-
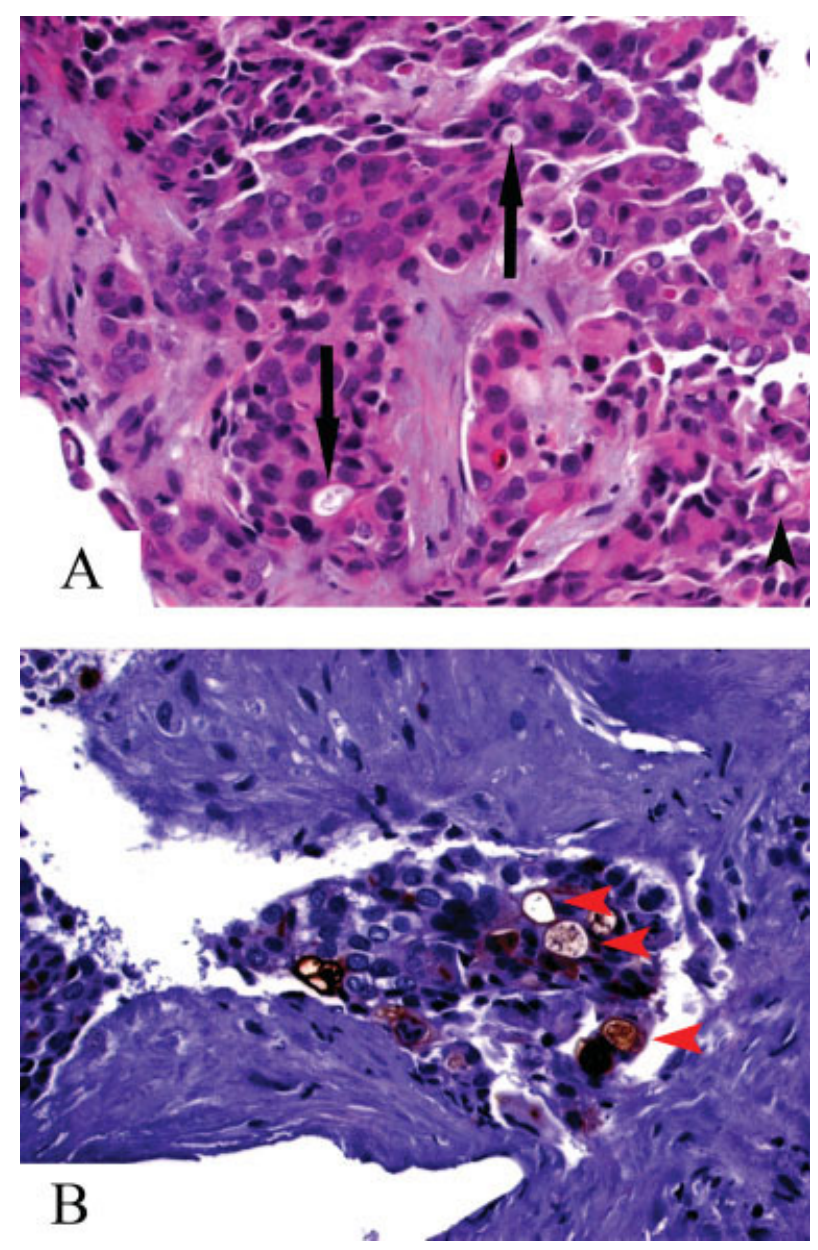

Fig. 2. (A) $H \& E$ stain shows neoplastic cells arranged in sheets and infiltrative cords. Duct differentiation is manifested by epithelial celllined ducts (arrow) and intracytoplasmic vacuoles (arrowhead) (core biopsy, H\&E, $\times 400)$. (B) Immunostain shows that intracytoplasmic vacuoles (arrowhead) are highlighted by polyclonal CEA antibody (core biopsy, CEA immunostain, $\times 400$ ). [Color figure can be viewed in the online issue, which is available at www.interscience.wiley.com.]

formed 1 week later. The biopsy revealed neoplastic cells arranged in sheets and infiltrative cords. The cells possessed abundant eosinophilic cytoplasm, pleomorphic and vesicular nuclei and occasional nucleoli. Various extent of duct differentiation was appreciated, which was manifested by epithelial cell-lined ducts or intracytoplasmic vacuoles. The tumor cells were positive for cytokeratin $5 / 6$ and cytokeratin 7 and the epithelial cell-lined ducts and intracytoplasmic vacuoles were highlighted by polyclonal CEA antibody (Fig. 2). The morphology and the immunoprofile were consistent with metastatic eccrine porocarcinoma.

\section{Discussion}

To date, less than 300 cases of EP have been reported in the English literature. ${ }^{16}$ Despite its rarity, the clinical and 
Table I. Comparison of EP and Selected Differential Diagnostic Entities

\begin{tabular}{|c|c|c|c|c|c|}
\hline Diagnosis & Cytoarchitecture & Cell boarders & Cytoplasm & Nucleus & $\begin{array}{c}\text { Intracytoplasmic } \\
\text { vacuole }\end{array}$ \\
\hline EP & $\begin{array}{l}\text { Round/oval cells dispersed } \\
\text { singly or in discohesive } \\
\text { clusters/sheets }\end{array}$ & Ill to well-defined & $\begin{array}{l}\text { Variable amount. } \\
\text { Vacuolated to dense } \\
\text { and refractile }\end{array}$ & $\begin{array}{l}\text { Pleomorphic, hyperchromatic. } \\
\text { Coarse chromatin. Occasional } \\
\text { prominent nucleoli }\end{array}$ & Present \\
\hline $\begin{array}{l}\text { Nonkeratinizing } \\
\text { SCC }\end{array}$ & $\begin{array}{l}\text { Round/oval cells dispersed } \\
\text { singly or in discohesive } \\
\text { two-dimensional geo } \\
\text { graphic sheets }\end{array}$ & Well-defined & $\begin{array}{l}\text { Variable amount. } \\
\text { Dense and refractile }\end{array}$ & $\begin{array}{l}\text { Hyperchromatic. Coarse } \\
\text { chromatin. Prominent } \\
\text { nucleoli }\end{array}$ & Absent \\
\hline $\mathrm{BCC}$ & $\begin{array}{l}\text { Tight clusters of tumor } \\
\text { cells with peripheral } \\
\text { palisading }\end{array}$ & Ill-defined & Scant & Small or inconspicuousnucleoli & Absent \\
\hline Met. AdC & $\begin{array}{l}\text { Single cells. Tight clusters } \\
\text { of round-oval cells that } \\
\text { attempt to form acini }\end{array}$ & Ill-defined & $\begin{array}{l}\text { Variable amount. } \\
\text { Formy or vacuolated }\end{array}$ & $\begin{array}{l}\text { Pleomorphic, } \\
\text { hyper/hypo-chromatic. Coarse } \\
\text { chromatin, prominent nucleoli }\end{array}$ & Present \\
\hline MM & $\begin{array}{l}\text { Single or loosely associated } \\
\text { epithelioid or spindle cells }\end{array}$ & Well-defined & $\begin{array}{l}\text { Melanin may be } \\
\text { seen }\end{array}$ & $\begin{array}{l}\text { Eccentric. Intranuclear } \\
\text { inclusions }\end{array}$ & Absent \\
\hline
\end{tabular}

EP, eccrine porocarcinoma; SCC, squamous cell carcinoma; BCC, basal cell carcinoma; Met. AdC, metastatic adenocarcinoma; MM, malignant melanoma.

histopathological features of EP have been well described. ${ }^{6,16}$ Data are limited, however, on the cytologic features of metastatic EP. Our case is the third reported describing the FNA cytology of metastatic EP. ${ }^{17,18}$

Similar to what previously described, ${ }^{17,18}$ FNA cytology of metastatic EP in the current case revealed discohesive clusters of tumor cells and single scattered cells. A majority of the cells had dense, refractile cytoplasm. Intracytoplasmic vacuoles were readily appreciable in some cells. Nuclear enlargement, high N/C ratio, nuclear pleomorphism, and hyperchromasia, and occasional prominent nucleoli were observed. Bi-and multinucleated tumor cells were also identified. Neither tumor necrosis, which was reported by the previous investigators nor individual apoptotic cells were identified in the current case. $^{17,18}$

The clinical presentation of EP may resemble both malignant and benign conditions such as squamous cell carcinoma in situ (Bowen's disease), invasive squamous cell carcinoma, basal cell carcinoma, amelanotic melanoma, metastatic carcinoma, seborrheic keratosis, verruca vulgaris, and pyogenic granuloma. ${ }^{10,15} \mathrm{EP}$ commonly presents as a verrucous plaque or nodule, up to $5 \mathrm{~cm}$ in diameter, with frequent ulceration. Definitive diagnosis relies on pathologic examination. EP may have some histologic overlap with eccrine poroma with a proliferation of basaloid to squamoid epithelium, broad based connection to the epidermis, and ductule lumina. Key to differentiating EP from eccrine poroma is identifying cytologic atypia, which may be high-grade. In addition, EP may demonstrate an infiltrative growth pattern, tumor necrosis and/or angiolymphatic invasion.

The cytologic features of metastatic EP are characteristic but by no means specific. Table I summarizes cytologic features of EP along the differential diagnoses. With regard to the current case in which the patient's past medical history was significant for EP and Bowen's disease, the cytologic differential diagnosis rested primarily between metastatic EP and metastatic nonkeratinizing squamous cell carcinoma. The aspirate did show tumor cells with features of squamous differentiation manifested by ill- to well-defined intercellular boarder, moderate to dense refractile cytoplasm. In addition, some tumor cells attempted to form and exhibited intracytoplasmic vacuoles. Combination of these findings strongly favored a diagnosis of EP over squamous cell carcinoma.

Besides metastatic squamous cell carcinoma, other malignant lesions should also be considered in the differential diagnoses of EP. The lesions include but are not limited to metastasis of basal cell carcinoma, melanoma and adenocarcinoma. Generally, metastatic basal cell carcinomas are rare. FNA biopsy revealed single and tight clusters of small, round tumor cells with hyperchromatic oval to spindle-shaped nuclei, minimal cytoplasm, high $\mathrm{N} / \mathrm{C}$ ratio, and inconspicuous or small nucleoli. Some of tumor cells in the clusters showed peripheral palisading. ${ }^{19-21}$

Metastatic melanoma is notorious for mimicking other tumors due to its various morphologic appearances. Classically, FNA biopsy reveals hypercellular smear with predominenetly single, epitheliod-looking cells. Multinucleation, large and eccentric nuclei, intranuclear inclusion, prominent nucleoli, and intracytoplasmic melanin pigments have been described in various degrees. ${ }^{22}$ It is noteworthy that rare variants of metastatic melanoma reveals other cell types, raising a diagnostic challenge. In this regard, metastatic melanomas with predominant population of spindle cell, lipid-rich balloon cell, signet-ring cell, and rhabdoid cell have been reported. ${ }^{23-26}$ Correlation of FNA cytologic findings with patient's known his- 
tory of melanoma and previous histologic findings (if available) plays a vital role in the diagnosis of metastatic melanoma. The diagnosis can be confirmed by positive immunostaining for S-100, MelanA, and/or HMB-45.

In the current setting, the presence of intracytoplasmic vacuoles, confirmed with positive immunostaining for polyclonal CEA antibody, was a critical finding allowing for accurate diagnosis of metastatic EP. However, we need to emphasize that the presence of intracytoplasmic vacuoles is not specific for EP. Other tumors particularly metastatic adenocarcinoma, e.g., lobular carcinoma of the breast, may exhibit the similar cytologic features. It is common that lobular carcinoma shows population of small, uniform, single tumor cells with eccentric nuclei and intracytoplasmic vacuoles containing targetoid inclusions. ${ }^{27}$ Although single cells may be seen in EP, it appears that EP tends to form clusters. Tumor cells of EP also exhibit more cytologic pleomorphism compared to that of lobular carcinoma, the latter is well known for bland, uniform appearance. As always, correlation of the cytological features with the clinical presentation is crucial for making a correct diagnosis in a challenge situation.

In summary, careful consideration of previous history is very important. Our experience suggests that there are unique cytopathologic features of metastatic EP and in the right setting such a cytologic diagnosis can be rendered.

\section{References}

1. Pinkus H, Mehregan AH. Epidermotropic eccrine carcinoma. A case combining features of eccrine poroma and paget's dermatosis. Arch Dermatol 1963;88:597-606.

2. Mishima Y, Morioka S. Oncogenic differentiation of the intraepidermal eccrine sweat duct: Eccrine poroma, poroepithelioma and porocarcinoma. Dermatologica 1969;138:238-250.

3. Girishkumar H, Kamineni S, Hwang RR, Levy J, Sadler R. Eccrine porocarcinoma. Dermatol Surg 1997;23:583-584.

4. Huet P, Dandurand M, Pignodel C, Guillot B. Metastasizing eccrine porocarcinoma: Report of a case and review of the literature. $\mathrm{J}$ Am Acad Dermatol 1996;35(5 Part 2):860-864.

5. Whitt P, Whelchel J, Ruff T. Eccrine porocarcinoma. Ear Nose Throat J 1996;75:536-538.

6. Robson A, Greene J, Ansari N, et al. Eccrine porocarcinoma (malignant eccrine poroma): A clinicopathologic study of 69 cases. Am J Surg Pathol 2001;25:710-720.

7. Mehregan AH, Hashimoto K, Rahbari H. Eccrine adenocarcinoma. A clinicopathologic study of 35 cases. Arch Dermatol 1983;119: 104-114.

8. Puttick L, Ince P, Comaish JS. Three cases of eccrine porocarcinoma. Br J Dermatol 1986;115:111-116.
9. Wollina U, Castelli E, Rulke D. Immunohistochemistry of eccrine poroma and porocarcinoma-More than acrosyringeal tumors? Recent Results Cancer Res 1995;139:303-316.

10. Shaw M, McKee PH, Lowe D, Black MM. Malignant eccrine poroma: A study of twenty-seven cases. Br J Dermatol 1982;107: 675-680.

11. Snow SN, Reizner GT. Eccrine porocarcinoma of the face. J Am Acad Dermatol 1992;27(2 Part 2):306-311.

12. Goedde TA, Bumpers H, Fiscella J, Rao U, Karakousis CP. Eccrine porocarcinoma. J Surg Oncol 1994;55:261-264.

13. Plunkett TA, Hanby AM, Miles DW, Rubens RD. Metastatic eccrine porocarcinoma: response to docetaxel (Taxotere) chemotherapy. Ann Oncol 2001;12:411-414.

14. Abenoza P, Ackerman A. Neoplasms with eccrine differentiation: Ackerman's histologic diagnosis of neoplastic skin diseases: A method by pattern analysis. Philadelphia: Lea \& Febš; 1990. p 415431.

15. Grimme H, Petres A, Bergen E, Wiemers S, Schopf E, Vanscheidt W. Metastasizing porocarcinoma of the head with lethal outcome. Dermatology 1999;198:298-300.

16. Gerber PA, Schulte KW, Ruzicka T, Bruch-Gerharz D. Eccrine porocarcinoma of the head: An important differential diagnosis in the elderly patient. Dermatology 2008;216:229-233.

17. Blandamura S, Altavilla G, Antonini C, Marchetti M, Piazza M. Porocarcinoma detected by fine needle aspiration biopsy of a node metastasis. A case report. Acta Cytol 1997;41(4 Suppl):1305-1309.

18. Bonadio J, Armstrong W, Gu M. Eccrine porocarcinoma: Report of a case with fine needle aspiration cytology, histopathology and immunohistochemistry. Acta Cytol 2006;50:476-480.

19. Giri DD, Gupta PK, Hoda RS. Cytologic diagnosis of metastatic basal cell carcinoma. Report of a case with immunocytochemical and molecular pathologic considerations. Acta Cytol 2000;44:232236.

20. Haddad MG, Silverman JF. Fine-needle aspiration cytology of metastatic basal cell carcinoma of the skin to the lung. Diagn Cytopathol 1994;10:15-19.

21. Henke AC, Wiemerslage SJ, Cohen MB. Cytology of metastatic cutaneous basal cell carcinoma. Diagn Cytopathol 1998;19:113-115.

22. Saqi A, McGrath CM, Skovronsky D, Yu GH. Cytomorphologic features of fine-needle aspiration of metastatic and recurrent melanoma. Diagn Cytopathol 2002;27:286-290.

23. Eckert F, Baricevic B, Landthaler M, Schmid U. Metastatic signetring cell melanoma in a patient with an unknown primary tumor. Histologic, immunohistochemical, and ultrastructural findings. J Am Acad Dermatol26(5 Part 2):870-875.

24. Kobayashi G, Cobb C. A case of amelanotic spindle-cell melanoma presenting as metastases to breast and axillary lymph node: diagnosis by FNA cytology. Diagn Cytopathol 2000;22:246-249.

25. Martinez F, Merenda G, Bedrossian CW. Lipid-rich metastatic balloon-cell melanoma: Diagnosis by a multimodal approach to aspiration biopsy cytology. Diagn Cytopathol 1990;6:427-433.

26. Slagel DD, Raab SS, Silverman JF. Fine needle aspiration biopsy of metastatic malignant melanoma with "rhabdoid" features. Frequency, cytologic features, pitfalls and ancillary studies. Acta Cytol 1997;41:1426-1430.

27. Ali S, Parwani A. Breast cytopathology (Essentials in cytopathology). New York: Springer; 2007. 